\title{
Oil Price Pass-through on Domestic Inflation: Oil Importing Versus Oil Exporting Countries
}

\author{
Siok Kun Sek ${ }^{1, *}$, Kivanç Halil Ariç ${ }^{2}$ and Jenq Fei Chu ${ }^{3}$ \\ ${ }^{1}$ Universiti Sains Malaysia, School of Mathematical Sciences, 11800 Minden, Penang, Malaysia \\ ${ }^{2}$ Cumhuriyet University, Faculty of Economics and Administrative Sciences, Department of International \\ Trade and Logistics, 58140 Sivas, Turkey \\ ${ }^{3}$ Universiti Sains Malaysia, School of Mathematical Sciences, 11800 Minden, Penang, Malaysia
}

\begin{abstract}
Previous studies have evident the effects of oil price changes on domestic inflation. However, such effects may vary due to oil dependency factor. This paper extends the examination on two panel groups, namely the oil importing and oil exporting countries. Each group consists of ten countries. Besides, we also compare the relative effects of oil price with other shocks (domestic output, exporter's production cost and real exchange rate) on domestic inflation (consumer price and producer price). Our results capture significant pass-through effect from oil price changes on domestic inflation at producer and consumer levels. However, oil price is not the main determinant to domestic inflation. The oil price pass-through effect differs between oil importing versus oil exporting groups across consumer and producer levels. Higher oil price causes to higher production price inflation but does not lead to higher consumer price inflation in both groups of countries. The oil price effect together with exchange rate, foreign cost production and GDP have significant long-run impact on domestic inflation in both groups of countries. The joint effects are small and not significant in the short-run. Oil dependency and effective monetary policy matter on determining the effect of oil price changes on domestic inflation.
\end{abstract}

Keywords: Oil price pass-through, consumer and producer price inflation, monetary policy.

\section{INTRODUCTION}

Oil price changes may have crucial effect on household spending, production activities and economic performance at national and international levels. Previous researches have provided evidences on the negative impacts of oil price fluctuations, in particular the oil price spikes to economy globally. On the other hand, the impacts of oil price changes may vary across economies especially between oil importing versus oil exporting countries as these countries show very different dependency on oil. The oil exporting countries have very low oil dependency while the oil importing countries are highly dependent on oil. Therefore, the effect of oil price changes may felt differently by these countries. In the global trade markets, each country is highly integrated. The impact of oil price changes may spread over the world through different transmission channels. For instance, oil price could be transmitted through cost channel as oil is the important source used in production. Higher oil price may lead to higher production cost. Higher production cost may lead to higher consumer price, hence higher inflation.

In this paper, we particularly focus on the impact of oil price pass-through on domestic inflation. Our main

*Address correspondence to this author at the University Sains Malaysia, School of Mathematical Sciences, 11800 Minden, Penang, Malaysia; Tel: +604- 6533888; Fax: +604-6570910; E-mail: sksek@usm.my objective is to compare the oil pass-through effect on domestic inflation at producer and consumer levels respectively. In particular, the study seeks to compare the results between main oil importing versus main oil exporting countries. In addition, we also conduct relative comparison between the effects of oil price changes and other macroeconomic factors on determining the inflation in these two groups of countries. The study may reveal important information on the oil transmission effect on domestic inflation which is useful for monetary policy decision and economy evaluation. Pooled mean group (PMG) technique is applied on the panel data to estimate the oil price pass-through equations denoted in ARDL models. Our results show that oil price is not the main determinant to domestic inflation. However, oil price changes can have significant effect but the effect is different at consumer versus producer levels and distinguishable between oil importing versus oil exporting countries. Higher oil price is harmful to inflation at producer level in both groups of countries. However, higher oil price is reported to have positive effect on consumer price level for oil importing group but no significant effect is found in that of oil exporting group. Despite affected by the oil dependency factor, the influence of oil price on domestic inflation can be also affected by the disinflation monetary policy.

The remaining paper is outlined as follows: section two summarizes the literature review; section three and 
four explains the data and methodology respectively; section five interprets the results and the last section concludes.

\section{LITERATURE REVIEW}

Previous studies have provided evidences on the direct and indirect effects of oil price changes on domestic price/ inflation. Such effects may vary over different time periods and also may change across industries/ countries. Indeed, a number of studies conducted comparison on the effects of oil price changes on economy activity and found that the impact of oil has declined over time. Prior to the year of 1970's, historical data/ records showed very strong effect of oil price spikes on economic growth and domestic price where oil price spikes were linked to low GDP growth or recession, high unemployment and high inflation (stagflation). On the other hand, high oil price fluctuations in the late 1990's and early 2000's did not cause to economic fluctuations in terms of higher inflation and the drop of growth (Fransisco, 2007). Therefore, such as Hooker (2002), Blanchard and Gali (2007) claims that the influences of oil price on economy have declined/ weakened over time. For instance, Hooker (2002) studied the relationship between oil prices and inflation based on two samples, i.e. $1962-1980$ and $1981-2000$. The results from the first sample showed that oil price had significance impact on inflation. No significance results were obtained from the second sample. Many studies also had proven on the decline relationship between oil price and inflation after mid-1980. Among these studies include Evans and Fisher (2011) and M. Chen and Y. Wen (2011). Other studies also detected on the decline of oil price pass-through on inflation, which among them include De Gregorio, Landerretche, Neilson, Broda, and Rigobon (2007), and Chen (2009). The possible factors contributing to such changes include energy efficiency as in Mankiw (2007), higher flexibility in labor markets and effective monetary policy as in Blanchard and Gali (2007) and may also due to the dependency on oil and the economic condition/ performance between the two different eras as mentioned by Kilian (2010). Despite these arguments, many studies still reported significant effects of oil price changes on economy especially on domestic price/ inflation. These studies include Kargi (2014), Abounoori, Nazarian, and Amiri (2014), Jiranyakul (2016) and Lacheheb and Sirag (2016).

The impact of oil price changes may vary across countries and industries. Comparing the impacts of oil price increases and decreases in oil importing versus oil exporting countries, Kazemi and Kazemikhasragh (2013) found that oil price increases impose asymmetric effects on the economies of oil importing countries but the impacts neutralize each other. On the other hand, oil price decreases induce reduction in production cost which lead to higher productivity and higher nominal wage in oil importing countries. The study also found that changes in oil prices cause to higher inflation in oil exporting group. The research conducted by the Bouakez and Vencatachellum (2007) focused on oil producing and oil importing countries using a dynamic stochastic general equilibrium model. The results found that monetary policy regime is crucial on determining the impacts of oil price on economy. Also, oil price increases lead to higher inflation in oil importing group but lower inflation in oil exporting group. Another study conducted by Baumeister, Peersman, and Van Robays (2010) on comparing the results between oil importing and oil exporting countries also revealed different reactions of consumer prices and monetary policy to oil shocks. Such differences results experienced in oil exporting versus oil importing countries may due to the oil dependency levels.

Some studies investigated the impact of oil price changes on domestic price at disaggregate levels and found that such impact vary across industries. Among them, significant impacts from oil price changes are found prices for industries of food (Ibrahim, 2015), agricultural (Zhang, Lohr, Escalante, \& Wetzstein, 2010) and transportation (Hansman, 2014). Castro, Jiménez-Rodríguez, Poncela, and Senra (2017) focused the investigation in Euro area (France, Germany, Italy and Spain). The results reveal that oil price changes have a large and direct effect on energy inflation but the impact to total inflation is weak. Also, the results reported none significance response from prices of goods and services to oil price shock. However, the results vary across countries and items due to differences in the structure of consumption and production, taxation and regulations and also differences in the indirect or second round effects. Many researches are conducted to compare the passthrough rate from oil price changes on domestic prices from different sectors/ category of items. These studies reported different pass-through rate from oil price on domestic prices across sectors/ items. Some studies suggest that high energy-intensive commodities experience stronger pass-through effect from oil price so that industries that are highly oil-intensive may more 
affected by oil price changes (Gao, Kim, \& Saba, 2013).

To be summarized, the effect of oil price changes may vary across industries and countries and changes over time. Oil intensity and oil dependency factors matter on determining the effect of oil price on economy in the level of sector and country respectively. Also, monetary policy is also influential to reduce the negative impact of oil price shock on economy.

\section{METHODOLOGY/MATERIALS}

The study is focused on two groups of countries, i.e. oil importing versus oil exporting countries. Each group of countries consists of 10 countries which are the main oil importing and oil exporting countries listed by the U.S. Energy Information Administration.

(1) Oil importing countries: China, India, Netherlands, Korea, Singapore, Italy, Japan, Germany, Spain, France.

(2) Oil exporting countries: Norway, Canada, U.K., Saudi Arabia, Kuwait, Russia, Iraq, Qatar, Nigeria, Kazakhstan.

The data are denoted in annual frequency ranging from 1980 to 2016. The data are collected from the Thomson Reuters Datastream. These data include gross domestic product, GDP (US\$), consumer price index, CPI, real effective exchange rate (REER) and producer price index (PPI) and crude oil price or OIL (US\$ per barrel). The PPI for U.S. is used to proxy for foreign production cost. All variables are transformed into natural log for consistency (LGDP, LPPI, LCPI, LPPI_US, LREER, LOIL).

The panel data analyses involve the following steps. In the first step, the preliminary tests (panel unit-root tests and panel cointegration tests) are conducted for the checking of stationarity and cointegration of variables. For this purpose, panel unit-root tests (Levin, Lin \& Chu (LLC) test, Im, Pesaran \& Shin (IPS) test and Fisher ADF test) are performed. In the next step, the information criterion of Akaika (AIC) is used to determine the lag length of ARDL models. In the third step, the oil price pass-through equations are constructed based on ARDL (autoregressive distributed lag) format. The pass-through equation for LCPI and LPPI are estimated using pooled mean group (PMG) technique for two groups of countries.

\subsection{The setup of Oil Price Pass-Through Equation}

The oil price pass-through equations are constructed based on the exchange rate pass-through (ERPT) equation. Applying the same concept explained in the exchange rate pass-through, the oil price passthrough rate is defined to be the measure on the percentage changed in domestic prices led by a one percentage changed in the oil price.

The ERPT is setup based on the law of one price (Sek \& Kapsalyamova, 2008) where the import price denominated in importing country's currency $P_{t}^{\text {im }}$ should equal to the price of export set in the exporting country's currency $P_{t}^{e x}$ multiplying by the exchange rate of importing country, $E_{t}$ so that

$$
P_{t}^{\text {im }}=P_{t}^{e x} \cdot E_{t} .
$$

The export price $P_{t}^{e x}$ is set based on the mark-up $\lambda_{t}$ over production cost marginally $C_{t}$ such that

$P_{t}^{e x}=\lambda \cdot C_{t}$

After substituting (2) into (1), we get this relationship: $P_{t}^{i m}=\lambda_{t} \cdot C_{t} \cdot E_{t}$. Applying log transformation, we reach the following ERPT equation:

$P_{t}^{i m}=\alpha_{1} \lambda_{t}+\alpha_{2} C_{t}+\alpha_{3} E_{t}$ or equivalently,

$C P I_{t}=\alpha_{1} G D P_{t}+\alpha_{2} P P I_{t}^{u s}+\alpha_{3} R_{E E R}$

where CPI is the proxy for import price, GDP is proxy for the mark-up and the exchange rate is represented by the real effective rate or REER. $\alpha_{3}$ the exchange rate pass-through coefficient which capture the partial elasticity of import price with respect to exchange rate. This equation is modified in estimating the passthrough effect of oil price on inflation by adding oil price as regressor in equation (3) so that we have:

$$
C P I_{t}=\alpha_{1} G D P_{t}+\alpha_{2} P P I_{t}^{u s}+\alpha_{3} \text { REER }_{t}+\alpha_{4} \mathrm{OIL}_{t}
$$

$\alpha_{4}$ is the measure on the oil price pass-through on domestic inflation.

\subsection{ARDL Model}

The autoregressive distributed lags model given $p$ lag of dependent variable and $q$ lag of independent variable or $\operatorname{ARDL}(p, q)$ takes the following format (Pesaran, Shin, \& Smith, 1999): 
$y_{i t}=\sum_{j=1}^{p} \lambda_{i j} y_{i t-j}+\sum_{j=0}^{q} \delta_{i j}^{\prime} x_{i t-j}+\varepsilon_{i t}$

where $i=1,2, \ldots, N$ indicating the number of countries; $t$ $=1,2, \ldots, T$ denotes the number of periods; the dependent variable, $y_{i t}$ and independent variable $x_{i t}$ are denoted in the $\mathrm{kx} 1$ vector; $\delta_{i j}^{*}$ is denoted as the $k \times 1$ coefficient vectors and $\lambda_{i j}$ as the vector of scalars. The disturbance term $\varepsilon_{i t}$ assumes to display the distribution with mean zero and a finite variance. The reparameterization of this equation to error correction form can be written as:

$\Delta y_{i t}=\phi_{i} y_{i t-1}+\beta_{i}^{\prime} x_{i t}+\sum_{j=1}^{p-1} \lambda_{i j}^{*} \Delta y_{i t-j}+\sum_{j=0}^{q-1} \delta_{i j}^{* *} \Delta x_{i t-j}+\varepsilon_{i t}$

where

$\phi_{i}=-1\left(1-\sum_{j=1}^{p} \lambda_{i j}\right) ; \beta_{i}=\sum_{j=0}^{q} \delta_{i j} ; \lambda_{i j}^{*}=\sum_{m=j+1}^{p} \lambda_{i m}, j=1,2, \ldots, p-1$

$\delta_{i j}^{*}=\sum_{m=j+1}^{q} \delta_{i m}, j=1,2, \ldots, q-1$.

By regrouping, equation (4) can be written as:

$\Delta y_{i t}=\phi_{i}\left(y_{i t-1}-\theta_{i}^{\prime} x_{i t}\right)+\sum_{j=1}^{p-1} \lambda_{i j} \Delta y_{i t-j}+\sum_{j=0}^{q-1} \delta_{i j}^{* \prime} \Delta x_{i t-j}+\varepsilon_{i t}$

$\theta_{i}=-\left(\frac{\beta_{i}}{\phi_{i}}\right)$ captures the long-run or equilibrium relationship among $y_{i t}$ and $x_{i t} \cdot \lambda_{i j}^{*}$ while $\delta_{i j}^{*}$ indicates the short run effects of independent variables on the dependent variables. The error-correction coefficient $\phi_{i}$ measures the speed of adjustment on $y_{i t}$ in attaining its long-run equilibrium due to changes in $x_{i t}$. This parameter is in negative value so that there is convergence to the long-run relationship. $\theta_{i}$ are the pass-through rate from independent variables into dependent variable.

Applying ARDL model on equation (4), our oil passthrough equations to be estimated are:

CPI equation: $L C P I=F\left(L G D P, L P P I \_U S, L R E E R, L O I L\right)(8 \mathrm{a})$

PPI equation: $L P P I=F\left(L G D P, L P P I \_U S, L R E E R, L O I L\right)(8 \mathrm{~b})$

where the dependent variable, y can be LCPI or LPPI while the independent variables include LGDP, LPPI_US, LREER and LOIL. Equation (8a) is the oil pass-through on CPI inflation while equation (8b) is oil pass-through on $\mathrm{PPI}$ inflation. Both equations are estimated using Pooled mean group (PMG) methods. PMG restricts the long-run parameters to be constant over all countries but allows the intercepts, short-run coefficients and error variances to be different across countries.

\section{RESULTS AND FINDINGS}

The unit-root tests reveal that all variables are stationary at first differenced or integrated of order one, I(1). Therefore, this fulfils the pre-condition to apply ARDL model, i.e. partial or all variables should be I(1). Since our unit-root tests show that all variables are integrated with order one or I(1), we are eligible to apply the ARDL model.

Our optimal lag length criterion is performed by limiting the comparisons of multiple combinations of $\operatorname{ARDL}(p, q, r, s, u)$ to lag 2. Akaika info criterion (AIC) suggests different model specifications, i.e. ARDL $(2,2,2,2)$ for oil importing countries (CPI and PPI equations) but $\operatorname{ARDL}(1,1,1,1)$ and $\operatorname{ARDL}(2,1,1,1)$ for oil exporting countries under $\mathrm{CPI}$ and $\mathrm{PPI}$ equations respectively. The results of PMG estimations are summarized in Table 1.

From Table 1, the results show that the long-run effects are relatively larger and more significant relative to the short-run effects which are small and not significant in majority cases. Comparing the long-run effects across countries, we observe that real exchange rate is the main determinant to domestic inflation for both groups of countries. In particular, real exchange rate appreciation leads to lower $\mathrm{CPI}$ and $\mathrm{PPI}$ inflation in oil importing countries as the value of currency increases, the spending power also increases. On the other hand, real exchange rate appreciation leads to lower CPI inflation in oil exporting countries but it causes higher PPI inflation in this group of countries. Appreciation in value of currency implies that domestic goods (in particular crude oil) are more expensive than foreign goods, so the export reduces and the cost is relatively higher.

GDP is also a significant determinant to domestic inflation in both groups of countries. Higher GDP or income leads to higher inflation at producer and consumer levels in oil importing group but it leads to lower inflation at producer level in oil exporting countries. Higher income may lead to higher spending or demand so that domestic prices increase. On the 
other hand, higher income may lead to higher production, the production price may increase probably due to higher quantity and cost of production while the drops of production may due to higher sales and higher productivity per worker.

Comparing the effect of oil price changes with other factors, the results show that oil price is not the main contributor to domestic inflation as its impact is relatively smaller than the impacts of other factors. Its impact at consumer level differs from that at producer level in both groups of countries. Higher oil price leads to higher production price or inflation through oil imports used for production activities. Therefore, higher world crude oil price is transmitted into production cost in both groups of countries. However, higher production cost does not pass-through on final consumer price in both groups of countries. In oil importing countries, oil price even leads to lower CPI inflation. This is probably due to disinflation policy implemented by the

Table 1: PMG Estimation

\begin{tabular}{|c|c|c|c|c|}
\hline \multirow{2}{*}{$\begin{array}{c}\text { Variable } \\
\text { Pass-through into }\end{array}$} & \multicolumn{2}{|c|}{ Oil Importing } & \multicolumn{2}{|c|}{ Oil Exporting } \\
\hline & LCPI & LPPI & LCPI & LPPI\# \\
\hline Long-run Parameter & & & & \\
\hline$L G D P_{i t-1}$ & $0.2019^{* * *}$ & $0.1966^{\star \star \star}$ & $0.1986^{\star \star \star}$ & $-0.3559^{* * *}$ \\
\hline$L_{R E E R_{i t-1}}$ & $-0.8017^{* * *}$ & $-0.8293^{\star * *}$ & $-0.3293^{* * *}$ & $0.4710^{\star * *}$ \\
\hline$L P P I \_U S_{i t-1}$ & $0.4599^{* * *}$ & $-0.3006^{\star *}$ & 0.1181 & $2.8123^{\star * *}$ \\
\hline $\operatorname{LOIL}_{i t-1}$ & $-0.0651^{* * *}$ & $0.1138^{\star * *}$ & 0.0113 & $0.4459^{\star * *}$ \\
\hline Speed of Adjustment & & & & \\
\hline$\phi_{i}$ & $-0.0675^{\star * *}$ & $-0.1440^{* * *}$ & $-0.1839^{* * *}$ & $-0.2346^{*}$ \\
\hline Short-run Parameter & & & & \\
\hline$\Delta L G D P_{i t}$ & 0.0116 & -0.0212 & -0.0174 & $0.1608^{*}$ \\
\hline$\Delta L G D P_{i t-1}$ & -0.1794 & -0.0320 & - & 0.0133 \\
\hline$\triangle L R E E R_{i t}$ & $0.0625^{\star *}$ & -0.0426 & -0.0832 & $-0.2040^{\star *}$ \\
\hline$\Delta L R E E R_{i t-1}$ & -0.0197 & -0.0650 & - & $-0.1925^{\star \star \star}$ \\
\hline$\Delta L P P I \_U S_{i t}$ & $0.2259^{\star * *}$ & $0.6942^{\star \star *}$ & 0.3453 & 0.4094 \\
\hline$\Delta P P I \_U S_{i t-1}$ & -0.0342 & -0.2035 & - & 0.0904 \\
\hline$\Delta L O I L_{i t}$ & -0.0065 & 0.0171 & -0.0264 & -0.0215 \\
\hline$\Delta L O I L_{i t-1}$ & -0.0005 & 0.0078 & - & -0.0222 \\
\hline$\Delta L C P I_{i t-1}$ & - & $0.1290^{*}$ & 0.0456 & - \\
\hline$\Delta L \mathrm{P} P I_{i t-1}$ & $0.4671^{* * *}$ & - & - & 0.4094 \\
\hline C & $0.0355^{\star * *}$ & $0.5603^{* * *}$ & - & -1.1402 \\
\hline trend & - & - & - & 0.0079 \\
\hline $\begin{array}{l}\text { Maximized } \\
\text { log-likelihood }\end{array}$ & 1190.724 & 924.3066 & 652.5774 & 509.8969 \\
\hline $\begin{array}{c}\text { Joint long-run effect } \\
\text { p-value } \\
\text { F-stat }\end{array}$ & $\begin{array}{c}0.000 \\
255.6553\end{array}$ & $\begin{array}{c}0.000 \\
261.3327\end{array}$ & $\begin{array}{c}0.000 \\
54.0630\end{array}$ & $\begin{array}{c}0.000 \\
78.0103\end{array}$ \\
\hline Model specifications & $\operatorname{ARDL}(2,2,2,2)$ & $\operatorname{ARDL}(2,2,2,2)$, & $\operatorname{ARDL}(1,1,1,1)$ & $\operatorname{ARDL}(1,2,2,2)$ \\
\hline
\end{tabular}

Note: ${ }^{*}$ indicates significance at $10 \% ;{ }^{* *} 5 \%$ and ${ }^{* * *}$ as $1 \%$ levels respectively. \# exclude Iraq, Qatar and Nigeria due to no data for PPI. 
policymaker that leads to rigidity/ stickiness in consumer price as shown in china (Tang, Wu, \& Zhang, 2010). On the other hand, oil price changes have no significant effect on CPI inflation in oil exporting countries. To be precise, the result reveal that oil price changes have negative effect on inflation at producer level, i.e. higher oil price may cause to higher production cost. However, higher oil price does not lead to higher inflation or higher price at domestic level in both groups of countries.

Testing on the joint long-run effect of LGDP, LREER, LPPI_US and LOIL reveal that these factors have joint long-run impact on determining the domestic inflation at consumer and producer levels respectively in both groups of countries.

\section{CONCLUSION}

We conduct panel data analyses on examining the effect of oil price pass-through on domestic price inflation at consumer and producer levels respectively. Comparative analyses are made between oil importing versus oil exporting countries. The pooled mean group (PMG) technique is applied on estimating the consumer and producer price inflation equations. Our results show that oil price pass-through has long-run significant effect on domestic inflation in both groups of countries. However, oil price is not the main determinant to domestic price inflation. Other factors (foreign producer cost, GDP and real exchange rate) also may determinant domestic inflation. These factors have significant long-run effect but limited short run effect on domestic inflation. Higher inflation is harmful at production level due to oil price pass-through on production price/ inflation which cause to higher production cost. This result holds in both groups of countries. However, higher oil price does not lead to higher consumer price/ inflation in both groups of countries. Higher oil price has no significant effect on consumer price inflation in oil exporting countries as oil exporting group is very low dependent on oil. On the other hand, the drops in the consumer price inflation in oil importing group may due to effective monetary policy that prevent the increment of prices at consumer level. Our results demonstrate that oil dependency factor and monetary policy matter on determining the effect of oil price changes on domestic inflation.

\section{ACKNOWLEDGEMENT}

This work was supported in part by FRGS under Grant No. 203/PMATHS/6711431.

\section{REFERENCES}

Abounoori, A. A., Nazarian, R., \& Amiri, A. (2014). Oil Price PassThrough into Domestic Inflation: The Case of Iran International Journal of Energy Economics and Policy, 4(4), 662-669.

Baumeister, C., Peersman, G., \& Van Robays, I. (2010). The economic consequences of oil shocks: differences across countries and time. Inflation in an era of relative price shocks, Reserve Bank of Australia, 91-128.

Blanchard, O. J., \& Gali, J. (2007). The Macroeconomic Effects of Oil Shocks: Why are the 2000s so different from the 1970s? https://doi.org/10.3386/w13368

Bouakez, H., \& Vencatachellum, D. (2007). The Impact of High Oil Prices on African Economies: African Development Bank.

Castro, C., Jiménez-Rodríguez, R., Poncela, P., \& Senra, E. (2017). A new look at oil price pass-through into inflation: evidence from disaggregated European data. Economia Politica, 34(1), 55-82. https://doi.org/10.1007/s40888-016-0048-9

Chen, \& Wen, Y. (2011). Oil price shocks and inflation risk. Economic Synopses. https://doi.org/10.20955/es.2011.19

Chen, M., \& Wen, Y. (2011). Oil price shocks and inflation risk. Economic Synopses, 2011(2011-07-06) https://doi.org/10.20955/es.2011.19

Chen, S.-S. (2009). Oil price pass-through into inflation. Energy Economics, 31(1), 126-133. https://doi.org/10.1016/j.eneco.2008.08.006

De Gregorio, J., Landerretche, O., Neilson, C., Broda, C., \& Rigobon R. (2007). Another pass-through bites the dust? Oil prices and inflation [with comments]. Economia, 7(2), 155-208. https://doi.org/10.1353/eco.2007.0014

Evans, C. L., \& Fisher, J. D. (2011). What are the implications of rising commodity prices for inflation and monetary policy? Chicago Fed Letter(May).

Fransisco, F. R. B. o. S. (2007). What Are the Possible Causes and Consequences of Higher Oil Prices on the Overall Economy? Retrieved from http://www.frbsf.org/education/ publications/doctor-econ/2007/november/oil-prices-impacteconomy.

Gao, L., Kim, H., \& Saba, R. (2013). How Does the Oil Price Shock Affect Consumers? https://doi.org/10.1016/j.eneco.2014.08.001

Hansman, J., McConnachie, D., Wollersheim, C., Elke, M. Hansen M., Chan, N., Crepin, M., Li, T, Peterson, E., \& Trani, A. (2014). The Impact of Oil Prices on the Air Transportation Industry Final Report.

Hooker, M. A. (2002). Are oil shocks inflationary?: Asymmetric and nonlinear specifications versus changes in regime. Journal of Money, Credit, and Banking, 34(2), 540-561. https://doi.org/10.1353/mcb.2002.0041

Ibrahim, M. H. (2015). Oil and food prices in Malaysia: a nonlinear ARDL analysis. Agricultural and Food Economics, 3(1), 2. https://doi.org/10.1186/s40100-014-0020-3

Jiranyakul, K. (2016). Oil price shocks and domestic inflation in Thailand. Browser Download This Paper. https://doi.org/10.2139/ssrn.2578836

Kargi, B. (2014). The Effects of Oil Prices On Inflation and Growth: Time Series Analysis In Turkish Economy For 1988: 012013: 04 Period.

Kazemi, Z., \& Kazemikhasragh, A. (2013). The Impact of Oil Price Fluctuations on Macro-Economic Variables of Demanding and Supplying Countries. International Monthly Refreed Journal of Research in Management and Technology, 2(4), 124-135.

Kilian, L. (2010). Oil price volatility: Origins and effects. Retrieved from https://www.econstor.eu/handle/10419/57602 
Lacheheb, M., \& Sirag, A. (2016). Oil price and inflation in Algeria: A nonlinear ARDL approach. Topics in Middle Eastern and African Economies, 18(2), 45-60.

Mankiw, G. (2007). Where have all the oil shocks gone? Retrieved from http://gregmankiw.blogspot.my/2007/10/where-have-alloil-shocks-gone.html https://doi.org/10.1016/S0262-4079(07)60708-8

Pesaran, M. H., Shin, Y., \& Smith, R. P. (1999). Pooled mean group estimation of dynamic heterogeneous panels. Journal of the American Statistical Association, 94(446), 621-634. https://doi.org/10.1080/01621459.1999.10474156
Sek, S., \& Kapsalyamova, Z. (2008). Pass-through of exchange rate into domestic prices: The case of four East Asian Countries. The International Journal of Economic Policy Studies, 3(3). https://doi.org/10.1007/BF03405706

Tang, W., Wu, L., \& Zhang, Z. (2010). Oil price shocks and their short-and long-term effects on the Chinese economy. Energy Economics, 32, S3-S14. https://doi.org/10.1016/j.eneco.2010.01.002

Zhang, Z., Lohr, L., Escalante, C., \& Wetzstein, M. (2010). Food versus fuel: What do prices tell us? Energy policy, 38(1), 445-451.

https://doi.org/10.1016/j.enpol.2009.09.034

DOI: https://doi.org/10.6000/1929-7092.2019.08.52

(C) 2019 Sek et al.; Licensee Lifescience Global.

This is an open access article licensed under the terms of the Creative Commons Attribution Non-Commercial License (http://creativecommons.org/licenses/by-nc/3.0/) which permits unrestricted, non-commercial use, distribution and reproduction in any medium, provided the work is properly cited. 